\title{
Louis Zweers
}

Alfred van Sprang, het gezicht van de Koude Oorlog

Zutphen (Walburg Pers), 1999, II9 p., f29,90, ISBN 59-5730-054-0

Journalist en kuristhistoricus Louis Zweers is inmiddels een bekende naam wanneer het gaat om publicaties op het gebied van de historische persfotografie. Zijn terrein bestrijkt vooral de nationale geschiedenis en in het bijzonder de activiteiten van Nederlandse militairen in het voormalig Nederlands-Indië van na

176 de Tweede Wereldoorlog. Als we de titels van zijn boeken lezer, valt op hoe dikwijls het gaat om foto's die door hun controversiële inslag niet eerder voor publicatie zijn vrijgegeven. 'Foute foto's', 'vergeten beelden' en 'verboden foto's' maken deel uit van enkele titels van eerder verschenen werk.

Wie in Zweers' nieuwste boek opnieuw onthullende foto's verwacht te zien, komt bedrogen uit. Alfred van Sprang was een fotograaf die in de jaren vijftig de ideologie van het 


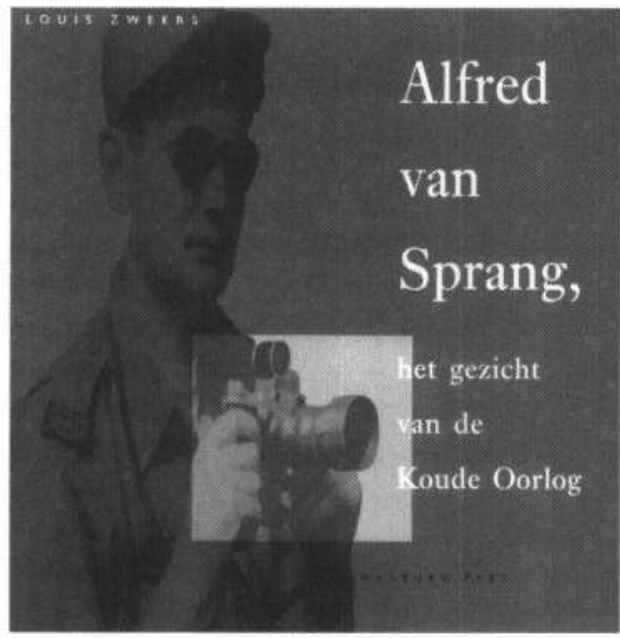

establishment met vuur verdedigde. Hij was met andere woorden een fel anti-communist. Van Sprang maakte foto- en radioreportages in dienst van de protestants-christelijke zuil. Hij was de belangrijkste fotograaf van het geillustreerde weekblad De Spiegel en reporter voor de NCRV-radio. In de periode daarvóór (19451949) was hij werkzaam als oorlogscorrespondent, gestationeerd in Nederlands-Indië, bij het Amerikaanse persbureau UPI. In 1960 maakte hij een overstap naar de televisie. Daar was zijn roem maar een kort leven beschoren; hij overleed in hetzelfde jaar.

Volgens Louis Zweers was Van Sprang een getalenteerd fotograaf, en ook een legendarische. Hij was zelfs, zoals de titel aangeeft, 'het gezicht van de Koude Oorlog'. Dat mag dan volgens Zweers zo zijn, het 'ware' gezicht (als dat al bestaat) was hij allerminst, eerder een van de vele gezichtspunten. Ook de aanduiding 'Koude Oorlog' slaat eerder op de periode die in dit boek centraal staat dan op de gebeurtenissen die Van Sprang fotografeerde. In de periode vanaf 1945 tot aan zijn dood in 1960 was Van Sprang als oorlogsfotograaf en -verslaggever getuige van een groot aantal internationale conflicten die strikt genomen zeker niet allemaal binnen het kader van de Koude Oorlog passen, wel binnen het proces van de dekolonisatie. Zo passeren onder meer de politionele acties in Nederlands-Indië (1947-1948), het debacle van de Kwomintang in China (1949), de Koreaanse oorlog (1950-1954), Indo-China begin jaren vijftig, de Russische bezettingen in Oost-Europa (jaren veertig en vijftig) en de dekolonisatieprocessen in Afrika (Brits-Kenia, BelgischKongo) de revue. Deze conflicten zijn min of meer als uitgangspunt genomen voor de indeling van het boek. In ieder hoofdstukje schetst Zweers een didactisch verantwoorde historische context, waarna hij vervolgens ingaat op het doen en laten van Van Sprang.

Van de drieduizend foto's - negatieven én contactafdrukken! - die Zweers in een kast van het Amsterdamse Fotopersbureau ABC Press vond, is in het boek een selectie opgenomen van 65 foto's. Vreemd genoeg bestaat meer dan helft van deze selectie uit foto's die Van Sprang tijdens zijn verblijf in Noord-Vietnam (Frans-Indochina) maakte. Slechts zeventien foto's zijn eerder gepubliceerd, in De Spiegel en de Haagsche Courant. Als (kunst)historicus zou Zweers toch moeten weten hoe belangrijk het is selectiecriteria te vermelden. Dit geldt des te meer wanneer de selectie in verhouding tot de rest van het boek onevenwichtig is. Ook in de contextbeschrijving van Vietnam wordt niet speciaal verwezen naar een eventueel grotere betrokkenheid, hooguit dat Van Sprang hier een wat langere periode vertoefde dan elders. Het aardige van deze reeks foto's is wel dat we nu eens niet de overgefotografeerde oorlog te zien krijgen vanaf het moment dat de Amerikanen er intensief bij betrokken raakten, maar beelden uit de periode daarvoor. Bovendien is deze reeks een soort reportage over het einde van de Franse koloniale heerschappij in dit gebied (april 1954-mei 1955). Behalve de Franse militairen worden ook de Vietminhsoldaten in beeld gebracht. Maar overeenkomstig het wereldbeeld van Van Sprang vond hij uiteraard de sabotage-acties van de Vietminh veel interessanter om te fotograferen dan de daden die het Franse leger weinig geliefd bij de bevolking maakte. Het beeld van de Franse militairen straalt voortdurend grote 
kalmte en rust uit, al sof ze uitsluitend op verlof waren.

Uit deze reeks rcept één foto in het bijzonder vraagtekens op. Op een kruising op de weg van Hanoi naar Haiphong staat een groepje Frans-koloriale soldaten, al kletsend en rokend, wat ontspannen rond te kijken - waarschijnlijk houden ze gewoon pauze. Op de voorgrond ligt het lijk van een Vietnamees jongetje - de lichaamshouding is te vreemd om het als 'slapen' te interpreteren. ledereen op de foto kijkt er letterlijk overheen en ook het bijschrift van Zweers (de foto is blijkbaar niet in de krant geplaatst) maakt geen melding van de tragiek of van de discrepantie tussen de houding van de soldaten en het lijk dat pal voor hun neus ligt. Moet deze foto aangeven dat Van Sprang me: zijn lens niet altijd de andere kant opkeek als de gruwelen van een oorlog zich aan hem opdrongen? Wij tasten in het duister. Wel wordt in het boek duidelijk dat Van Sprang, in welk oorlogsgebied dan ook, meestal graag in een comfortabele omgeving verkeerde. Zweers vergeet nooit te vermelden in welk fameus of luxueus hotel Van Sprang nu weer logeerde. Zijn verblijf aan het front zelf zal steeds van korte duur zijn geweest. Opnieuw overeenkomstig zijn wereldbeeld keek Van Sprang niet alleen vaak de andere kant op, maar ook nog eens in één bepaalde richting: zo fotografeerde hij niet Mao, maar Tsjang Kai-sjek en dienovereenkomstig niet zozeer het Chinese platteland, maar de Britse kroonkolonie Hongkong en nationalistisch Taiwan; hij fotografeerde niet de Mau Mau (behalve als gevangenen) maar de Britse kolonisator of de Kikuyu-burgerwacht, de rechterhand van de Britten. In dit opzicht mag en kan hij dan ook niet het gezicht van de Koude Oorlog worden genoemd.

Tot besluit. Het valt toe te juichen dat er opnieuw een publicatie op het gebied van de Nederlandse persfotografie is verschenen. Toch is vaak een van de manco's van dergelijke publicaties de scheve verhouding tussen tekstinhoud en afgedrukte foto's. Juist persfotografie - in tegenstelling tot kunstfotografie - behoeft niet alleen uitgebreide contextbeschrijvingen, maar ook een nauwkeurige beeldanalyse. Dat laatste ontbreekt ten enenmale in het boek van Louis Zweers. De auteur hanteert een wat conventionele benadering, waarin naast een uiteenzetting van het conflict vooral de biografie van de fotograaf voldoende duidelijkheid over de genomen foto's moet verschaffen. Dit leidt zelfs tot onverkwikkelijke en niet ter zake doende speculaties over Van Sprangs voortijdige dood (wurgseks of post-traumatische stress stoornis?). Ook een grondiger tekstredactie had het leesgenot verhoogd. Om kort te gaan: waardevol genoeg vanwege de foto's, maar met heel wat gemiste kansen wat de inhoudelijke kant betreft.

Bernadette Kester 